\title{
Population size and survivorship for juvenile lemon sharks (Negaprion brevirostris) on their nursery grounds at a marine protected area in Brazil
}

\author{
Renato Hajenius Aché de Freitas ${ }^{1,2}$, Ricardo S. Rosa ${ }^{2}$, Bradley M. Wetherbee ${ }^{3}$ \\ and Samuel H. Gruber ${ }^{4}$
}

\begin{abstract}
Sharks face a number of obstacles for surviving their first several years of life and many species occupy nursery areas. Although estimates of survival, particularly for young age classes, are essential for assessing, monitoring and effectively managing animal populations, there have been relatively few calculations of survival within shark populations and even fewer estimates based on direct methods for sharks on their nursery grounds. We used tag-recapture methods to estimate the population size and survival of juvenile lemon sharks (Negaprion brevirostris) on their nursery grounds at Atol das Rocas, a marine protected area in Brazil. Sharks were sampled from1999 to 2003. Population size estimates ranged from 12 to 100 juvenile sharks and survival estimates ranged between $24-54 \%$ with a mean of $44.6 \%$ over the most robust sampling periods. The population of juvenile lemon sharks declined over the course of our study, whereas survival rates may have increased over the same time period. Even a modest level of fishing and removal of mature females in adjacent areas may dramatically affect small populations of sharks within a small and isolated nursery such as Atol das Rocas. The lower survival rates and population size at Atol das Rocas could be the result of differences in physical characteristics of this nursery in comparison to others used by lemon sharks in the northwestern Atlantic. Such comparatively lower populational parameters suggest that the population of young lemon sharks is fragile at the Atol das Rocas nursery.
\end{abstract}

Os tubarões enfrentam muitos obstáculos para sobreviver nos primeiros anos de vida e muitas espécies ocupam áreas de berçário. Embora estimativas de sobrevivência, particularmente para jovens, sejam essenciais para acessar, monitorar e manejar efetivamente populações animais, existem poucos cálculos destas estimativas para populações de tubarões e poucas estimativas baseadas em métodos diretos para estes animais em suas áreas de berçário. Métodos de marcação e recaptura foram utilizados no presente estudo para estimar o tamanho populacional e a sobrevivência de jovens tubarões-limão (Negaprion brevirostris) em uma área de berçário na Reserva Biológica do Atol das Rocas, Brasil. Os indivíduos foram amostrados entre 1999 e 2003 e as estimativas de tamanho populacional variaram entre 12 a 100 indivíduos jovens e a taxa de sobrevivência entre 24 e $54 \%$, com média de 44,6\% durante o período de amostragem mais robusto. A população destes tubarões jovens diminuiu ao longo de nosso estudo, ainda que as taxas de sobrevivência tenham aumentado durante o mesmo período. Mesmo um nível moderado de pesca e a remoção de fêmeas maduras em áreas adjacentes podem afetar dramaticamente pequenas populações de tubarões num berçário pequeno e isolado como o Atol das Rocas. As taxas de sobrevivência e tamanho populacional relativamente mais baixos em Rocas podem ser resultado das diferenças nas características físicas deste berçário, comparadas a outros utilizados pela espécie no Atlântico norte-ocidental. Tais parâmetros comparativamente mais baixos no Atol das Rocas sugerem a fragilidade da população jovem de tubarões-limão neste berçário.

Key words: Mortality, Tag-recapture, Atol das Rocas, Conservation, Carcharhinidae.

${ }^{1}$ Laboratório de Fisiologia Animal e Comportamento, Research Center on Animal Welfare - RECAW, Departamento de Fisiologia, Instituto de Biociências, UNESP, 18618-000 Botucatu, SP, Brazil.rhafreitas@gmail.com

2Departamento de Sistemática e Ecologia, CCEN, Universidade Federal da Paraíba, 58059-900 João Pessoa, PB, Brazil. rsrosa7@yahoo.com.br ${ }^{3}$ Department of Biological Sciences/ University of Rhode Island, Kingston, RI 02881, U.S.A. wetherbee@mail.uri.edu

${ }^{4}$ Bimini Biological Field Station and University of Miami, Rosenstiel School of Marine and Atmospheric Science, Miami, FL 33149-1098, U.S.A.sgruber@rsmas.miami.edu 


\section{Introduction}

Many species of sharks have life history characteristics (such as low fecundity, late sexual maturity and slow growth) that make them vulnerable to overfishing and this, in combination with elevated fishing pressure over the past several decades, has led to dramatic declines in shark populations (Baum et al., 2003; Baum \& Myers, 2004). Particularly sharp declines in shark abundance and consequent further effects on coral reef ecosystems have been noted at a number of locations (Roberts, 1995; Bascompte et al., 2005; Robbins et al., 2006). In the USA and several other countries, management measures have been enacted to curtail overfishing of shark populations and to encourage rebuilding of stocks at sustained fishing levels. Particular emphasis should be allocated to enhance survival of juvenile sharks through measures such as the identification of essential habitat and delineation of nursery areas (NMFS, 1993, 2003; Hoenig \& Gruber, 1990; Cortés, 1998).

Mortality is a critical factor in determining the status of fished species (Heupel \& Simpfendorfer, 2002) and there have been some attempts to estimate survival within shark populations. Mortality at specific ages among shark populations has been estimated based on life history characteristics and from tag-recapture information (e.g. Grant et al., 1979; Smith \& Abramson, 1990; Simpfendorfer, 1999; Xiao et al., 1999). Survival of juvenile sharks in specific nursery areas has been estimated through the use of tagging data as well as acoustic telemetry methods (e.g. Manire \& Gruber, 1993; Gruber et al., 2001; Heupel \& Simpfendorfer, 2002). However, nursery areas for many shark species comprise numerous small, discrete locations scattered over a large geographical range and their local environmental characteristics may be highly variable (Simpfendorfer \& Milward, 1993; Heupel et al., 2007; Wetherbee et al., 2007). Environmental variability is a key factor influencing the biology of an organism; hence, mortality estimates may vary among the nursery areas of a particular species. Considering such variability is imperative for realistic estimates of local population demographics, as well as for broader assessment of the status of entire stocks and for evaluation of management practices in rebuilding or sustaining populations. Thus, knowing the population size and survival estimates of a species over a broad range of nursery areas is fundamental for accurate assessment of population changes and effective management and conservation of the species.

The lemon shark (Negaprion brevirostris) is an ideal candidate for comparing population structure and survivorship among nurseries. This species utilizes relatively small, discrete nursery areas throughout its range from Florida, through the Caribbean and south to Brazil (Feldheim et al., 2001). It also exhibits life-history characteristics that make it vulnerable to overfishing (Holden, 1974; Hoenig \& Gruber, 1990; Gruber et al., 2001) and has been the subject of studies estimating the juvenile mortality (Manire \& Gruber, 1993; Gruber et al., 2001;
DiBattista et al., 2008). The lemon shark is currently listed as an endangered species in Brazil (MMA, 2004), but there are no studies focusing the conservation of its populations or juvenile mortality rates in South Atlantic nurseries. We studied a population of lemon sharks within a nursery at Atol das Rocas, Brazil, which differs substantially from typical nursery areas used by this species. The atoll is remote, lacks seagrass beds and mangroves that typify most nurseries used by lemon sharks in the North Atlantic, and experiences tidal extremes as great as $3 \mathrm{~m}$ (Wetherbee et al., 2007). The environmental uniqueness of this nursery appears to be reflected in differences between the biology of young lemon sharks at Atol das Rocas and at other well-studied nurseries such as Bimini, Bahamas. For example, young lemon sharks at Atol das Rocas grow faster (Brown \& Gruber, 1988; Barker et al., 2005; Freitas et al., 2006), exhibit different feeding habits (Cortés \& Gruber, 1990; R. S. Rosa, pers. obs.) and markedly different movement patterns (Morrissey \& Gruber, 1993; Wetherbee et al., 2007). Such differences between the two nurseries most likely influence survival. Therefore, we hypothesized that the population size and survival rates of lemon sharks would differ between the Rocas nursery and the Bimini nursery.

The goals of this study were to estimate population size and survival rates of juvenile lemon sharks in their nursery grounds at Atol das Rocas, to discuss and compare these estimates with values calculated for Bimini, and to point out some of the needed conservation measures for the species in this marine protected area (MPA).

\section{Material and Methods}

Study site. Atol das Rocas ( $03^{\circ} 52^{\prime} \mathrm{S} 33^{\circ} 49^{\prime} \mathrm{W}$ ) is the only atolllike structure in the western South Atlantic Ocean, located $267 \mathrm{~km}$ off the coast of Brazil east of the city of Natal (Oliveira-Filho \& Ugadim, 1976). In 1979, Atol das Rocas was designated as the first MPA in Brazil and fishing is considered illegal within the $1,000 \mathrm{~m}$ isobath (Silva et al., 2002). Rocas is currently uninhabited with the exception of small transient teams of researchers and environmental wardens.

The atoll consists of two sandy islands (Farol Island and Cemitério Island) that are the only dry land exposed during high tide, whereas at low tide much of the atoll coralline algae reef perimeter and sandy interior are exposed, with the exception of a central lagoon, and a variety of natural pools (Fig. 1). At high tide, a small tidal creek (Baía da Lama) is formed within the confines of a peninsula and the eastern shore of Farol Island. At peak high tide, the tidal creek is approximately $350 \mathrm{~m}$ x $35 \mathrm{~m}$ and $1.5 \mathrm{~m}$ in depth. Groups of juvenile lemon sharks enter the creek with the rising tide and exit with the outgoing tide (Oliveira, 2001; Freitas et al., 2006; Wetherbee et al., 2007).

Sampling. Juvenile lemon sharks (0-4 years of age) were 


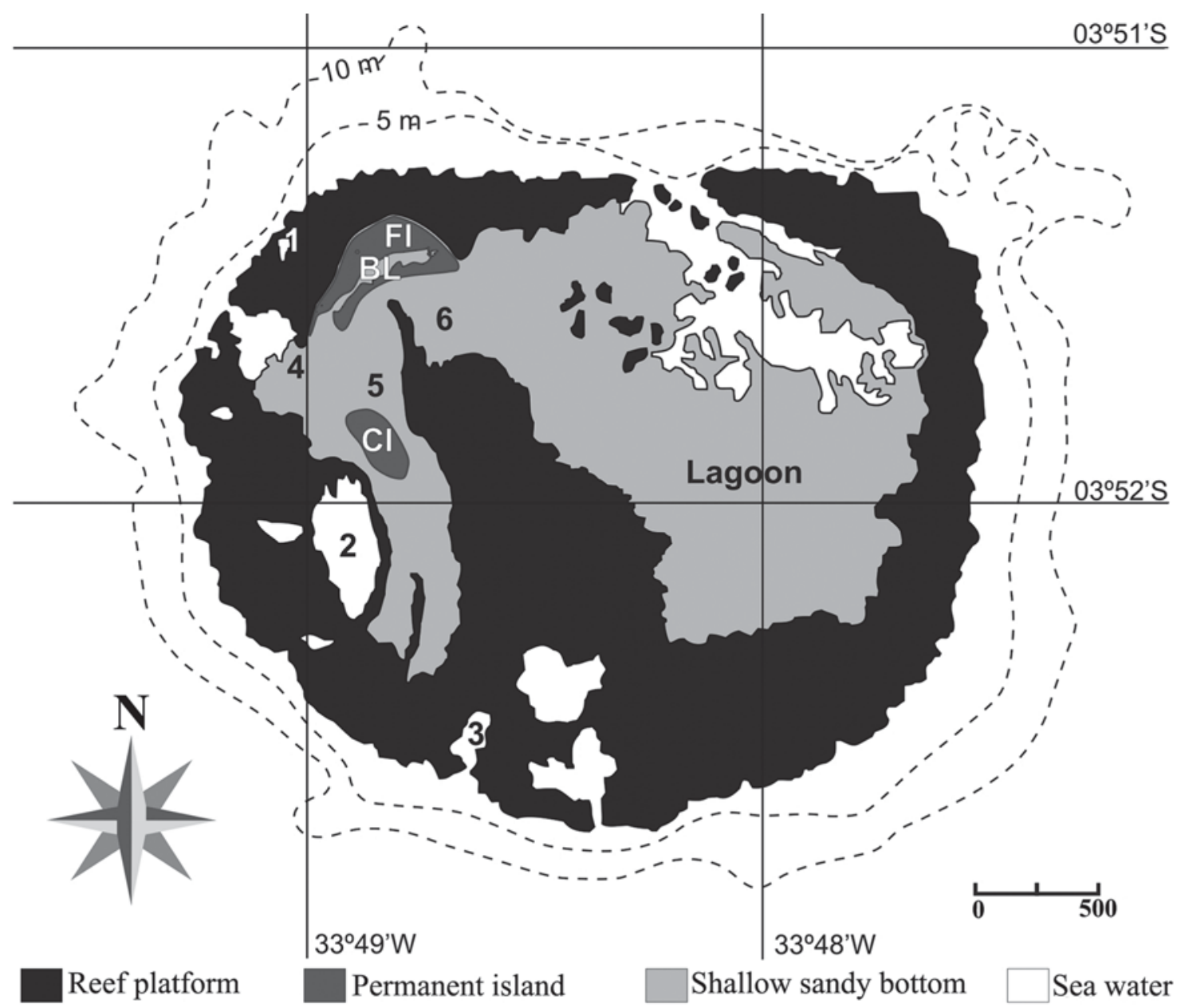

Fig. 1. Map of the Atol das Rocas Biological Reserve off Brazil, showing the sampling sites: BL = Baía da Lama (total capture $(\mathrm{tc})=272), 1$ = Farol Pool (tc = 29), 2 = Cemitério Pool ( $(\mathrm{tc}=25), 3$ = Podes Crer Pool (tc = 3), 4 = Barretinha (tc = 6), $5=$ Lagoon, North of Cemitério Island (tc = 5), 6 = Lagoon, South of Farol Island (tc = 7). CI = Cemitério Island, FI = Farol Island. Broken lines represent the 5 and $10 \mathrm{~m}$ isobaths.

captured during nine 20-day expeditions between March 1999 and October 2003, mainly with monofilament gill nets (2 m high, $10 \mathrm{~cm}$ stretched-mesh). Four to six sampling events with gill nets were conducted in each expedition at Baía da Lama, during spring tides, when substantial numbers of sharks entered the creek during high tide. The other sites were randomly chosen and sampled independent of the tidal cycle, with gill nets, dipnets and longline. Due to logistic constrains, longlining was limited to two expeditions (1999 and 2000) and dip-netting was limited to handling few individuals, whereas gill-netting was the most efficient method to sample juvenile lemon sharks at size classes targeted in this study. Sampling sites are indicated in Fig. 1.

Reliance on the Baía da Lama as the major sampling site was predicated on the success of previous studies in capturing large numbers of sharks at one time at that single location (Oliveira, 2001). A concurrent study on habitat use of young lemon sharks (Wetherbee et al., 2007) revealed that lemon sharks repeatedly returned to Baía da Lama at high tide the year round, whether they were initially tagged there or tagged at other locations within the atoll. Therefore, sampling at the tidal creek enabled a relative estimate of the number of young lemon sharks present within the atoll at any one time.

All captured sharks were measured, sexed and tagged with a passive integrated transponder (PIT-tag) implanted under the skin near the first dorsal fin (Gruber et al., 1988; Manire \& Gruber, 1991; Feldheim et al., 2002; Freitas et al., 2006). For the majority of sharks, a small fin clip (2 mm in diameter) was taken for use in a genetic study (Feldheim et al., 2001).

Visual censuses. Visual censuses were also used to access the number of lemon sharks that utilize the main occurrence site for this species within Atol das Rocas. These censuses were conducted at Baía da Lama both at rising and receding tides by observers positioned on the shore near the entrance of the creek. The narrow entrance and the shallow, clear water usually enabled easy detection of sharks either entering or leaving the creek. 
Population size and survival. The shark catch information, including the number of captures, recaptures, newly tagged and number of released individuals was used to determine the population size and survival using three different models.

The Schumacher-Eschemeyer model for closed populations (Krebs, 1999) was used to estimate the population size of lemon sharks at the atoll, with each expedition considered as a separate and distinct sampling event. Therefore, multiple recaptures within each expedition (referred to as over-recaptures) were used in these calculations, but not the recaptures among expeditions. The closed population assumption was presumed valid because births and deaths can be regarded as negligible within the time span of each expedition (20 days). Furthermore, immigration and emigration are unlikely for juvenile lemon sharks based on the isolated location of the atoll and their demonstrated high degree of site fidelity (Morrissey \& Gruber, 1993; Wetherbee et al., 2007). Calculations employed the algorithm provided by Krebs (1999).

The Jolly-Seber method was also used to estimate the population size and to calculate survivorship based on pooled data of all expeditions (Krebs, 1999), but under the assumption that the population is open rather than closed. Due to the absence of recaptures in August 2002, it was not possible to pool the data of all expeditions in one data set for the JollySeber method, because the algorithm does not permit the absence of intermediate recaptures. Therefore, this analysis was done separately for the two data sets (March 1999 to November 2001 and August 2002 to October 2003). The two sampling periods were large enough and include the parturition-season (from February to May - Freitas et al., 2006) so that births and deaths likely occurred and therefore, the population must to be treated as open. Calculations were based on the algorithms provided by Krebs (1999).

Because juvenile lemon sharks do not move long distances and exhibit a high degree of site fidelity at Atol das Rocas (Wetherbee et al., 2007), it was also possible to calculate survivorship estimates for short periods after birth by a "direct method of inference", described in Krebs (1999). Knowing a reliable total number of live individuals at the beginning $\left(\mathrm{N}_{\text {start }}\right)$ and the end $\left(\mathrm{N}_{\text {end }}\right)$ of any period, survivorship is $\mathrm{N}_{\text {end }} / \mathrm{N}_{\text {start }}$. The survivorship estimates by this direct method of inference were calculated for distinct time intervals only between the August 2002 and October 2003 expeditions. Counts of sharks at the beginning and the end of each sampling period were more reliable after August 2002, when total catches were lower and nearly all juvenile sharks were likely captured during the expeditions. It was possible to infer the birth month for any captured shark using the total length at capture and the von Bertalanffy growth function (VBGF) obtained by Freitas et al. (2006) and this tool could prevent the bias of treating a non-recaptured shark as dead in the direct method of inference. Thus, we could ascertain if any particular shark was alive during previous trips, before it was initially captured and tagged and to include it in the analyses. For example, when shark \# 411C41594F was captured in March 2003 it was $80.0 \mathrm{~cm}$ total length (TL), which according to the VBGF corresponded to birth during April-May 2002. Therefore, this shark would have been alive and present at the atoll during the August 2002 expedition, although it was not captured.

Both the Jolly-Seber method and the direct method of inference were used to calculate survival estimates for all combined age classes ( $0-4$ years of age) as well as for age- 0 class (young of the year), but the former method failed to provide reliable estimates for age-0 class before August 2002, due to the low number of recaptures in this size class.

Sharks that had been tagged were easily recognized in subsequent captures by the presence of a scar resulting from the PIT tag implantation, and by a scar on the fins resulting from the removal of a tissue sample for genetic study. All sharks identified as recaptures by these scars possessed a functional PIT tag, indicating that the PIT-tags were not lost or shed during the study. Although there are some assumptions for markrecapture models in field studies - random sampling, every individual with same probability of capture, every tagged individual with same probability of surviving, individuals not shedding their tags during the sampling period, and tags not overlooked at capture (Krebs, 1999), the study site and the experiment delineation were appropriate for compliance with the major features of these models.

\section{Results}

Juvenile lemon sharks were captured a total of 347 times during the study. This total represented 157 different individuals, with 155 recaptured within the same expedition (over-recaptures), and 35 sharks recaptured during subsequent expeditions (Table 1). The number of sharks detected in visual censuses at Baía da Lama during expeditions ranged between 11-58 individuals (Table 1).

A total of 336 sharks were captured in gill nets or dipnets and 11 were caught on longlines (four in March 1999 and seven in March 2000). Sharks ranged in size from 58 to $157 \mathrm{~cm}$ TL, corresponding to 0-4 years of age (Brown \& Gruber, 1988; Freitas et al., 2006). Sharks were captured at different sites within the atoll, including the central lagoon and pools (Podes Crer, Cemitério and Farol, see Fig. 1), but 75\% were caught in Baía da Lama, predominantly in gill nets, as the sharks left the tidal creek with the outgoing tide.

Population estimates by the Schumacher-Eschemeyer method ranged from 12 to 100 individuals, with the smallest populations sizes (12-25) estimated during the last six expeditions (Table 2). We consider that the Jolly-Seber method yielded only three reliable population estimates (Table 2). For the first and last data set of each time interval it was not possible to estimate the population using Jolly-Seber and this method yielded some gross overestimations because of the small percentage of sharks tagged in some periods. Population estimates for age- 0 sharks could be calculated for two time intervals only, and were 8 and 15 individuals, respectively for March and May 2003. 
Survival rates of juvenile lemon sharks based on the JollySeber method for the three time intervals (Table 2) ranged from 24.2\% (from March to September 2000) to a high of 54.1\% (between August 2002 and March 2003). Annual survivorship estimated for three different time periods by the direct method of inference ranged from $37.1 \%$ to $46.6 \%$ (Table 3), and the mean $( \pm$ S.D.) survival rate of lemon sharks of $0-4$ years of age for all combined methods based on post 2002 time intervals was $44.6 \pm 6.5 \%$. Survival rates for age- 0 sharks based on post 2002 time intervals ranged from $40 \pm 2 \%$ to $54 \pm 1 \%$ (mean+S.E.) according to the Jolly-Seber method, and from $27.7 \%$ to $48.0 \%$ (mean \pm S.D. $=37 \pm 1 \%$ ) by the direct method of inference (Table 3).

\section{Discussion}

The population of juvenile lemon sharks at Atol das Rocas may be considered closed when each expedition is analyzed separately, based on observations that these sharks, and young lemon sharks in general, restrict their movements to a limited area and have high site fidelity (Morrissey \& Gruber, 1993;

Table 1. Number of tagged, over-recaptured (individuals recaptured one or multiple times within the same expedition), recaptured sharks, total capture events and maximum number of visually recorded shark per expedition.

\begin{tabular}{lccccccccccc}
\hline & Mar & Mar & Sep & Mar & Nov & Aug & Mar & May & Oct & \multirow{2}{*}{ Total } \\
& 1999 & 2000 & 2000 & 2001 & 2001 & 2002 & 2003 & 2003 & 2003 & \\
\hline Tagged & 30 & 49 & 27 & 9 & 6 & 12 & 10 & 10 & 4 & 157 \\
Over-recapture & 9 & 31 & 9 & 2 & 9 & 18 & 27 & 26 & 24 & 155 \\
Recapture & 0 & 0 & 10 & 1 & 4 & 0 & 3 & 8 & 9 & 35 \\
Total Captures & 39 & 80 & 46 & 12 & 19 & 30 & 40 & 44 & 37 & 347 \\
Visual Census & 58 & 41 & - & - & - & 11 & 15 & 15 & 14 & - \\
\hline
\end{tabular}

Wetherbee et al., 2007) and also because of the large distance between Rocas and the nearest location with suitable nursery habitat. Furthermore, given the short duration of each expedition, we presumed that mortality could be regarded as negligible over the 20 days time span of one expedition.

Based on data collected during individual expeditions from 1999 to 2000, our estimates of the lemon shark population were considerably smaller (54, 57, 67 and 100 sharks) than estimate obtained by a different method in another study. Oliveira (2001) used the Schnabel method to obtain a population estimate of 147 juvenile lemon sharks in Atol das Rocas, based on eight sampling events between September 1999 and September 2000. One possible explanation for the different estimates obtained in these two, partially overlapping studies is that Oliveira (2001) calculated population size based on a closed population model over the span of twelve months, but would have in reality encompassed at least some gain (births) and losses (deaths) to the population. Because of differences in methodology it was difficult to make direct and valid comparisons between our population estimates and those proposed by Oliveira (2001).

DiBattista et al. (2008) sampled 91-138 young lemon sharks (age-0 and age-1) per year with gill nets, rod and reel or longline fishing gear in Bimini between 1996 and 2000. In spite of the differences in sampling methodology, the results indicate that the two nurseries are dissimilar in the number of young lemon sharks, and probably in the number of sharks born each year, the number of pregnant females that give birth annually, and ultimately in population size. An intuitive explanation for such differences is that Rocas is smaller than Bimini and hence supports a smaller population, but other ecological aspects could be involved. More studies at these two sites are needed to verify why these differences occurred and whether they are still valid.

Our data suggested that the population of lemon sharks

Table 2. Population size and survival rate. CL (confidence limits). Mean ( \pm S.E.). "nd” = non-determined and "g.o.” = gross

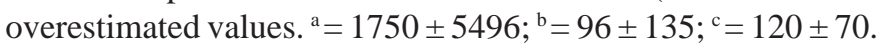

\begin{tabular}{clccccccccc}
\hline & & Mar & Mar & Sep & Mar & Nov & Aug & Mar & May & Oct \\
& & 1999 & 2000 & 2000 & 2001 & 2001 & 2002 & 2003 & 2003 & 2003 \\
\hline \multirow{3}{*}{ Schumacher-Eschemeyer } & Population size & 54 & 57 & 100 & 25 & 12 & 13 & 14 & 18 & 13 \\
& CL of 90\% & $37-101$ & $44-84$ & $66-209$ & $16-58$ & $9-20$ & $11-15$ & $12-16$ & $18-19$ & $13-14$ \\
& CL of 95\% & $34-128$ & $41-94$ & $61-271$ & $14-90$ & $9-23$ & $11-16$ & $11-17$ & $18-19$ & $12-14$ \\
\hline \multirow{2}{*}{ Jolly-Seber } & Tagged (\%) & nd & 2 & 29 & 18 & 46 & nd & 29 & 47 & 71 \\
& Population size & nd & g.o. $^{\text {a }}$ & $67 \pm 44$ & g.o. & nd & nd & $17 \pm 6$ & $17 \pm 0$ & nd \\
& Survival (\%) & g.o. $^{{ }^{b}}$ & $24 \pm 16$ & $38 \pm 44$ & nd & nd & $40 \pm 18$ & $54 \pm 14$ & nd & nd \\
\hline
\end{tabular}

Table 3. Annual survival rate for sharks between 0 to 4 years old and for age- 0 sharks estimated by direct method of inference. $\mathrm{N}_{\text {start }}=$ total number of alive sharks at the beginning of period and $\mathrm{N}_{\text {end }}=$ total number of alive sharks at the end of period.

\begin{tabular}{|c|c|c|c|c|c|}
\hline & Period & $\mathrm{N}_{\text {start }}$ & $\mathrm{N}_{\text {end }}$ & Time (year) & Survival rate (\%) \\
\hline \multirow{4}{*}{0 to 4 years old } & From Aug 2002 to Oct 2003 & 13 & 5 & 1.25 & 46.6 \\
\hline & From Mar 2003 to Oct 2003 & 22 & 13 & 0.67 & 45.4 \\
\hline & From May 2003 to Oct 2003 & 23 & 14 & 0.5 & 37.1 \\
\hline & Mean ( \pm S.D.) & - & - & - & $43 \pm 5$ \\
\hline \multirow{4}{*}{ age-0 } & From Aug 2002 to Oct 2003 & 5 & 2 & 1.25 & 48.0 \\
\hline & From Mar 2003 to Oct 2003 & 18 & 9 & 0.67 & 35.4 \\
\hline & From May 2003 to Oct 2003 & 19 & 10 & 0.5 & 27.7 \\
\hline & Mean ( \pm S.D.) & - & - & - & $37 \pm 10$ \\
\hline
\end{tabular}


at Rocas declined over the course of the study. In March of 1998 two of us (R. S. Rosa and S. H. Gruber) observed 64 lemon sharks in the tidal creek during high tide. In following years (1999-2000) the number of sharks observed during the first months of the year by Oliveira (2001) at this location ranged from 20 to 60 , which is in close agreement with numbers observed in our study (58 sharks in March 1999, 41 sharks in March 2000). In more recent years (2002-2003) we observed fewer than 15 sharks during high tide in Baía da Lama at the same time of year. The decline in lemon shark population based on visual observations over the course of this study is also indicated by our estimates of population size based on tag and recapture data (see Tables 1-2).

There are a number of possible explanations for a decline in the lemon shark population over the short period of time spanned by our study. Firstly, the large Rototags used by Oliveira (2001) appeared to have impaired growth of sharks carrying these tags (Freitas et al., 2006) and there is some evidence that these sharks suffered higher rates of mortality than sharks not carrying Rototags. Survival rates estimated by the same method (see Table 2) were 24\% for sharks both carrying or not Rototags (from March to September 2000), but more than $40 \%$ for sharks without Rototags (after 2002). A second possible explanation is that the population declined as part of a natural fluctuation in birth rate, such those expected in response to wide ranging climatic events (Dulvy et al., 2003), or resulting from a small, asynchronous, and variable number of pregnant females giving birth at the atoll each year.

It is also possible that removal of large lemon sharks (mature or pregnant females) in fisheries could have contributed to a decrease in the number of newborn sharks over time. Illegal fishing boats were frequently seen around the periphery of the atoll and occasionally these boats were observed capturing large sharks. For example, as many as ten boats were simultaneously detected at Rocas by the radar scan of the R/V Seward Johnson during both the 1999 and the 2000 expeditions. Observation of an adult lemon shark being landed in a fishing boat in 1999 (A. L. F. Castro, pers. com.) and of a dead nurse shark (total length $=128 \mathrm{~cm}$ ) found stranded with a gunshot wound to the head in 2003 (R. H. A. Freitas, pers. obs.) is further evidence of occasional poaching of sharks at the atoll. The philopatric behavior of lemon sharks to nursery areas (Feldheim et al., 2004) would compound the effects of removal of a small number of mature females that had historically given birth at Rocas. Although such impacts would affect the total population of young lemon sharks at the atoll, juvenile lemon sharks occupied areas of the atoll not visited by fishers, and therefore fishing likely influenced the infusion of newborn sharks into the system each year, but not necessarily survival of the young sharks after they were born.

Based on an average litter size of 8-10 young (Feldheim et al., 2001) and a gestation period of 10-12 months (Compagno, 1984), a total of five to seven females could have accounted for the 52 age-0 sharks captured in March and September 2000, whereas only three or four females giving birth at the atoll would have been necessary to contribute the 23 age- 0 individuals captured or observed in March and May 2003. These observations suggest that the number of full-term females giving birth at the atoll decreased during the study, and their capture by the illegal fishery within the MPA or in fisheries over a broader area is a possibility.

A population that is dependent upon a small number of reproducing females that are philopatric to a nursery area in combination with typical k-selected life history characteristics (Holden, 1974; Branstetter, 1990; Cortés, 1998; Baum et al., 2003) could easily undergo relatively large changes in size as a result of even modest fishing pressure or habitat destruction (Gruber \& Parks, 2002). These effects are further exacerbated at isolated locations distant from other nurseries. The population decline for lemon sharks at Rocas is illustrative of the need for enforcement of no-take policies within MPAs and of the difficulty of maintaining the effectiveness of MPAs at remote locations, where minor poaching may have farreaching effects on the local ecosystem and on the conservation of endangered species (Stevens et al., 2000; Fowler et al., 2002; Robbins et al., 2006).

Survival rates ranging from $24 \%$ to $54 \%$ were estimated for lemon sharks in their first four years of life at Rocas. A clear inequality exists between the overall survival rates estimated based on data from March and September of 2000 (24.2\%) compared with rates estimated on data after 2002 (mean $=44.6 \%)$. Increased survival of sharks during later segments of our study might reflect decreased mortality of young lemon shark following the cessation of the use of Rototags in 2000, or else, an increased availability of resources due to reduced competition at lower population densities.

Survival rate for age-0 sharks was considerably lower during their first six months of life (27.7 to 35.4\%) when compared to survival between the sixth to $12^{\text {th }}$ month of life (48.0\%), suggesting that mortality is especially high immediately after birth (from February to May at Rocas - Freitas et al., 2006). Our mean survival estimate for the age- 0 sharks are lower than other estimates for the Bimini nursery ( $47.5 \%$ by Manire \& Gruber, 1993 and 57.1\% by DiBattista et al., 2008).

The mean survival rate for juvenile lemon sharks that we estimated based on post-2002 data is within the range of survival estimates at Bimini, but it is lower than the mean of these estimates. Gruber et al. (2001) obtained 14 survival estimates ranging from 38 to $90 \%$ (mean $=57 \%$ ) for sharks of 0 3 years of age, based on four different models, including tagrecapture methods. Recently, and after an exhaustive sampling, DiBattista et al. (2008) estimated the survival ranging from 41 to $64 \%$ (age- 0 and age- 1 ) with a mean of $54.2 \%$.

The physical differences between the nursery at Atol das Rocas and Bimini are striking. The Bimini nursery is characterized by shallow, sandy and seagrass substrate, confined within mangrove-lined shoreline with a relatively narrow tidal range, such that this habitat is available to the sharks at all tidal stages (Morrissey \& Gruber, 1993; Gruber et al., 2001). Morrissey \& Gruber (1993) found that juvenile lemon sharks at Bimini exhibited a high degree of site fidelity and made repeated movements within consistent near-shore, 
shallow locations and often moved through or even rested within the mangroves. These sharks frequently revisited preferred areas and persisted in well-defined locations, limiting their movements within about $5 \%$ of the available shoreline. Rocas lacks mangroves and seagrass flats, experiences a tidal range in excess of $3 \mathrm{~m}$ and juvenile lemon sharks there must repeatedly move between high and low tide refuge areas rather than remain within a single location (Wetherbee et al., 2007). Young lemon sharks at Rocas have a higher rate of growth than sharks at Bimini, possibly as a result of greater prey availability at Atol das Rocas (Freitas et al., 2006). Assuming that the various models provided reliable survival estimates for each situation, the differences in habitat, behavior and life history traits of young lemon sharks at these two nurseries could account for the differences in mean survival at the two locations. Variable selection pressures can occur at these two nurseries and result in differential survival rates and population sizes. Movement patterns of lemon sharks at both Rocas and Bimini and those of blacktip sharks in a Florida nursery all appear directly related to predator avoidance, and habitat use of many species of sharks in their nurseries may similarly be heavily influenced by predator-prey relations (Morrissey \& Gruber, 1993; Heupel \& Heuter, 2002; Wetherbee et al., 2007).

Although there have been few estimates of survival in elasmobranchs, mortality and other life history characteristics are essential components of demographic models and other methods used to assess the status of shark populations (Cortés, 1998; Simpfendorfer, 1999; Mollet \& Caillet, 2002). Because many species of shark utilize small, discrete nursery areas, which sometimes vary greatly in their biotic and abiotic characteristics, the most accurate and reliable evaluations of populations will account for variations in the biology and behavior of young sharks within a variety of nursery areas and will not rely solely on information from a single nursery and extrapolate limited data to larger populations (Cortés \& Parsons, 1996). Accordingly, our study suggests that survival of juvenile lemon sharks is different between two very dissimilar nursery areas. This may be typical for populations that utilize a variety of nursery areas, but the comparatively lower population size and survival at Rocas suggest that young lemon sharks are fragile in this nursery.

\section{Acknowledgements}

We thank to Maurizélia de Brito Silva, IBAMA, Rebio Atol das Rocas, Projeto Tamar, Fundação Pró-Tamar for access to the reserve and logistic assistance; to NSF and CNPq for supporting the international cooperative program "Natural history of lemon shark at Atol das Rocas and Fernando de Noronha, Brazil”; National Geographic Society for financial support for several expeditions in 2001-2003; CNPq supported RSR with a research grant. We also thank Rose Mann and Lacey Hoover for their kind efforts to secure private funding; we are indebted to the Hoover Foundation, Tadashi and Toshi Fujino for generous personal support. We gratefully acknowledge the following corporate support: Mario Aiello, owner of Davey Marine; the late Dan Schaad of Mercury Division, Brunswick Corporation; Destron-Fearing Corporation, especially Sean Casey; and Pelican Products.

We are grateful to Captain James Seiler and the crew of the R/V Seward Johnson; to Kevin Feldheim, Tim Calver, Stan Spielman, Melissa Drake, Tony DiGirolamo, John Hoeing, Alexandre Jost, Albano Schulz and the many Brazilian and US students for their assistance in the field work; and to Captain José Martino Silva of the sailing vessel Delícia. We thank Bertran Feitoza for developing the map and Gustavo Dafferner for the finished edition of this figure. We recognize with thanks Maria Cristina Crispim, Rosângela Lessa, and Malva Medina Hernández for suggestions and criticisms on this paper, which was part of the senior author's MS thesis defended at Universidade Federal da Paraíba in 2004 and supported by CNPq. This study was awarded as best student presentation by the Neotropical Ichthyological Association during the XVI Meeting of the Brazilian Ichthyological Society (SBI) in 2005.

\section{Literature Cited}

Barker, M. J., S. H. Gruber, S. P. Newman \& V. Schluessel. 2005. Spatial and ontogenetic variation in growth of nursery-bound juvenile lemon sharks, Negaprion brevirostris: a comparison of two age-assigning techniques. Environmental Biology of Fishes, 72: 343-355.

Bascompte, J., C. J. Melián \& E. Sala. 2005. Interaction strength combinations and the overfishing of a marine food web. Proceedings of the National Academy of Sciences, 102: 5443-5447.

Baum, J. K., R. A. Myers, D. G. Kehler, B. Worm, S. J. Harley \& P. A. Doherty. 2003. Collapse and conservation of shark populations in the Northwest Atlantic. Science, 299: 389-392.

Baum, J. K. \& R. A. Myers. 2004. Shifting baselines and the decline of pelagic sharks in the Gulf of Mexico. Ecology Letters, 7: 135-145.

Branstetter, S. 1990. Early life-history implications of selected carcharhinoid and lamnoid sharks of Northwest Atlantic. Pp: 17-28. In: Pratt, H. L., S. H. Gruber, T. Taniuchi (Eds.). Elasmobranchs as living resources: advances in the biology, ecology, systematics, and the status of the fisheries. Seatle, NOAA Technical Report NMFS 90, 518p.

Brown, C. A. \& S. H. Gruber. 1988. Age assessment of the lemon shark, Negaprion brevirostris, using tetracycline validated vertebral centra. Copeia, 1988(3): 747-753.

Compagno, L. J. V. 1984. FAO Species Catalogue. Sharks of the world. An annotated and illustrated catalogue of shark species known to date. FAO Fisheries Synopsis 125, 4(2), 655p.

Cortés, E. 1998. Demographic analysis as an aid in shark stock assessment and management. Fisheries Research, 39: 199-208.

Cortés, E. \& S. H. Gruber. 1990. Diet, feeding habits, and estimates of daily ration of young lemon sharks, Negaprion brevirostris (Poey). Copeia, 1990: 204-218.

Cortés E. \& G. R. Parsons. 1996. Comparative demography of two populations of bonnethead shark (Sphyrna tiburo). Canadian Journal of Fisheries and Aquatic Sciences, 53: 709-718.

DiBattista, J. D., K. A. Feldheim, S. H. Gruber \& A. P. Hendry. 2008. Are indirect genetic benefits associated with polyandry? Testing predictions in a natural population of lemon sharks. 
Molecular Ecology, 17: 783-795.

Dulvy, N. K., Y. Sadovy \& J. D. Reynolds. 2003. Extinction vulnerability in marine populations. Fish Fisheries, 4: 25-64.

Feldheim, K. A., S. H. Gruber \& M. V. Ashley. 2001. Population genetic structure of the lemon shark (Negaprion brevirostris) in the western Atlantic: DNA microsatellite variation. Molecular Ecology, 10: 295-303.

Feldheim, K. A., S. H. Gruber \& J. R. C. de Marignac. 2002. Genetic tagging to determine passive integrated transponder tag loss in lemon sharks. Journal of Fish Biology, 61: 1309-1313.

Feldheim, K. A., S. H. Gruber \& M. V. Ashley. 2004. Reconstruction of parental microsatellite genotypes reveals female polyandry and philopatry in the lemon shark, Negaprion brevirostris. Evolution, 58(10): 2332-2342.

Fowler, S. L., T. M. Reed \& F. A. Dipper. 2002. Elasmobranch Biodiversity, Conservation and Management: Proceedings of the International Seminar and Workshop, Sabah, Malaysia, July 1997. IUCN SSC Shark Specialist Group. IUCN, Gland, Switzerland and Cambridge, UK, 258p.

Freitas, R. H. A., R. S. Rosa, S. H. Gruber \& B. M. Wetherbee. 2006. Early growth and juvenile population structure of lemon sharks Negaprion brevirostris in the Atol das Rocas Biological Reserve, off north-east Brazil. Journal of Fish Biology, 68: 1319-1332.

Grant, C. J., R. L. Sandland \& A. M. Olsen. 1979. Estimation of growth, mortality and yield per recruit of the Australian school shark, Galeorhinus australis (Macleay), from tag recoveries. Australian Journal of Marine and Freshwater Research, 30: 625-637.

Gruber, S. H., J. R. C.de Marignac \& J. M. Hoenig. 2001. Survival of juvenile lemon sharks at Bimini, Bahamas, estimated by markdepletion experiments. Transactions of the American Fisheries Society, 130: 376-384.

Gruber, S. H., D. Nelson \& J. Morrissey. 1988. Patterns of activity and space utilization of lemon sharks, Negaprion brevirostris in a shallow Bahamian lagoon. Bulletin of Marine Science, 43: 61-76.

Gruber, S. H. \& W. Parks. 2002. Mega-resort development on Bimini: sound economics or environmental disaster? Bahamas Journal of Science, 9: 2-18.

Heupel, M. R., J. K. Carlson \& C. A. Simpfendorfer. 2007. Shark nursery areas: concepts, definition, characterization and assumptions. Marine Ecology Progress Series, 337: 287-297.

Heupel, M. R. \& R. E. Heuter. 2002. Importance of prey density in relation to the movement patterns of juvenile blacktip sharks (Carcharhinus limbatus) within a coastal nursery area. Marine Freshwater Research, 53: 543-550.

Heupel, M. R. \& C. A. Simpfendorfer. 2002. Estimation of mortality of juvenile blacktip sharks, Carcharhinus limbatus, within a nursery area using telemetry data. Canadian Journal of Fisheries and Aquatic Sciences, 59(4): 624-632.

Hoenig J. M. \& S. H. Gruber. 1990. Life-history patterns in the elasmobranchs: implications for fisheries management. Pp: 116. In: Pratt, H. L., S. H. Gruber, T. Taniuchi (Eds.). Elasmobranchs as living resources: advances in the biology, ecology, systematics, and the status of the fisheries. Seatle, NOAA Technical Report NMFS 90, 518p.

Holden, M. J. 1974. Problems in the rational exploitation of elasmobranch populations and some suggested solutions. Pp. 117-138. In: Harden-Jones, F. R. (Ed.) Sea fisheries research. London, Elek Science, 510p.

Krebs, C. J. 1999. Ecological Methodology, $2^{\text {nd }}$ ed. Menlo Park, Addison-Welsey Educational Publishers, Inc, 620p.

Manire, C. A. \& S. H. Gruber. 1991. Effect of M-type dart tags on field growth of juvenile lemon sharks. Transactions of the
American Fisheries Society, 120: 776-780.

Manire, C. A. \& S. H. Gruber. 1993. A preliminary estimate of natural mortality of age-0 lemon sharks, Negaprion brevirostris. NOAA Technical Report NMFS, 115: 65-71.

MMA - Ministério do Meio Ambiente. 2004. Lista Nacional das Espécies de Invertebrados Aquáticos e Peixes Ameaçados de Extinção. Instrução Normativa n ${ }^{0}$ 5, de 21 de maio de 2004. Diário Oficial da República Federativa do Brasil, Brasília, DF.

Mollet, H. F. \& G. M. Cailliet. 2002. Comparative populations demography of elasmobranchs using life history tables, Leslie matrices and stage-based models. Marine Freshwater Research, 53: 503-516.

Morrissey, J. F. \& S. H. Gruber. 1993. Habitat selection by juvenile lemon sharks, Negaprion brevirostris. Environmental Biology of Fishes, 38: 311-319.

NMFS - National Marine Fisheries Service. 1993. Fishery Management Plan for Sharks of the Atlantic Ocean. NOAA/NMFS, Southeast Fisheries Science Center, US Department of Commerce, 167p.

NMFS - National Marine Fisheries Service. 2003. Final Amendment 1 to the Fishery Management Plan for Atlantic Tunas, Swordfish and Sharks. NOAA/NMFS, Southeast Fisheries Science Center, US Department of Commerce, 512p.

Oliveira, P. G. V. 2001. Levantamento da fauna de elasmobrânquios e estudo da biologia comportamental do tubarão limão, Negaprion brevirostris (Poey, 1868), tubarão lixa, Ginglymostoma cirratum (Bonnaterre, 1788) na Reserva Biológica do Atol das Rocas, RN-Brasil. Unpublished Dissertation, Universidade Federal de Pernambuco, Recife, PE, Brazil, 114p.

Oliveira-Filho, E. C. \& Y. Ugadim. 1976. A survey of the marine algae of Atol das Rocas (Brazil). Phycologia, 15: 41-44.

Robbins, W. D., M. Hisano, S. R. Connolly \& J. H. Choat. 2006. Ongoing collapse of coral-reef shark populations. Current Biology, 16(23): 2314-2319.

Roberts, C. M. 1995. Effects of fishing on the ecosystem structure of coral reefs. Conservation Biology 9: 988-995.

Silva, M. B., C. E. T. Campos \& S. G. Targino. 2002. Atol das Rocas: primeira unidade de conservação marinha do Brasil e único atol do Oceano Atlântico Sul. Gerenciamento Costeiro Integrado, 2: 27-28.

Simpfendorfer, C. A. \& N. E. Milward. 1993. Utilization of a tropical bay as a nursery area by sharks of the families Carcharhinidae and Sphyrnidae. Environmental Biology of Fishes, 37: 337-345.

Simpfendorfer, C. A. 1999. Mortality estimates and demographic analysis for the Australian sharpnose shark, Rhizoprionodon taylori, from northern Australia. Fishery Bulletin, 97: 978-986.

Smith, S. E. \& N. J. Abramson. 1990. Leopard shark Triakis semifasciata distribution, mortality rate, yield, and stock replenishment estimates based on tagging study in San Francisco Bay. Fishery Bulletin, 88: 371-381.

Stevens, J. D., R. Bonfil, N. K. Dulvy et al. 2000. The effects of fishing on sharks, rays, and chimaeras (chondrichthyans), and the implications for marine ecosystems. Journal of Marine Science, 57: 476-494.

Wetherbee, B. M., S. H. Gruber \& R. S. Rosa. 2007. Movement patterns of juvenile lemon sharks (Negaprion brevirostris) within Atol das Rocas, Brazil: a nursery characterized by tidal extremes. Marine Ecology Progress Series, 343: 283-293.

Xiao, Y., J. D. Stevens \& G. J. West. 1999. Estimation of fishing and natural mortalities from tag experiments with exact or grouped times at liberty. Canadian Journal of Fisheries and Aquatic Sciences, 56(5): 868-874.

Accepted April 2009

Published June 17, 2009 